\title{
Assessing the Effect of External Debt Servicing and Receipt on Exchange Rate in Nigeria
}

\author{
Nwanne, T. F. I. ${ }^{1} \&$ Eze Onyekachi Richard ${ }^{2}$ \\ ${ }^{1}$ Department of Accounting/Finance, Faculty of Management and Social Sciences, Godfrey Okoye University, \\ Enugu \\ ${ }^{2}$ Department of Banking and Finance, Ebonyi State University, Abakaliki, Nigeria \\ Correspondence: Eze Onyekachi Richard, Department of Banking and Finance, Ebonyi State University, P.M.B \\ 053 Abakaliki-Nigeria. E-mail: ezerich2014@gmail.com
}

Received: June 23, 2015

Accepted: August 11, 2015

Online Published: August 25, 2015

doi:10.5539/ijef.v7n9p278

URL: http://dx.doi.org/10.5539/ijef.v7n9p278

\begin{abstract}
The aim of this study is to investigate the relationship between external public debt servicing and receipt and exchange rate fluctuations in Nigeria from 1981 to 2013. The variables used in the study included external public debt receipts, external public debt servicing, and exchange rate. The theoretical models adopted in the study were the monetary model of exchange rate determination and the monetary approach to international capital movements. The strategies for accomplishing stated objectives were specified to include the use of Ordinary Least Square (OLS) multiple regression and cointegration test, which would have helped in determining the short-run and long-run relationships, respectively, between the specified variables, based on secondary data sourced from Central Bank of Nigeria (CBN) and Debt Management Office (DMO) statistical publications for the period under review. The findings of the study showed that external debt receipts and external debt servicing have positive short and long-run relationships with naira exchange rate fluctuations. The study concluded that whereas external public debt receipts affect exchange rate positively, external public debt servicing affects exchange rate negatively. The policy implication of this study is that Nigerian government should evolve more efficient external debt management strategies that will ensure that foreign loan receipts secured net off the effects of the servicing obligations in order to enhance the value and exchange rate of the naira. The paper recommended that Nigerian government should always strive to secure self-liquidating, production/project-based external loans for financing projects, place and enforce embargo on certain classes of foreign loans as well as on the frequency of contracting loans, contract foreign loans with concessionary low interest rates and long maturity periods, promptly and regularly service foreign loans to avoid the burdensome effect of accumulated compound interests, and appropriate external loan resources properly.
\end{abstract}

Keywords: exchange rate, public debt, servicing, receipt, foreign loan

\section{Introduction}

The public sector, comprising of all organizations not privately owned and operated, but established, run and financed by the government on behalf of the public (Adams, 2013), like the private sector, requires fund for its numerous activities which go beyond its internal revenue generation capacity. The public sector must of necessity borrow to fill the gap between its receipts and expenditure. Public sector debt, both domestic and external, is a stock of liabilities with different tenures accumulated by government operations in the past and scheduled to be fully repaid by government in the future (CBN, 2010). It covers only recognized direct financial obligations of government on which government pays interest on redemption.

Ugwu (2011) noted that public debts help in maintaining economic stability, development of productive enterprises, meeting emergencies, prosecution of war and meeting current deficits. Internal debts, which are debts raised domestically, do not give rise to net additions to the country's capital formation, rather they end up diverting funds which naturally would have been available for private sector investment to the public sector. Such debts encourage public sector competition over scarce available local investible funds. In view of the limitations surrounding the use of domestic debts, governments reach out for foreign debts which have the potential of increasing incomes as additional resources are injected into the domestic economy. Foreign or external debts are those debts owed by individuals, firms, or government of one country to residents of another 
country or international agencies (Black, 2002). According to Anyafo (1996), government debts have the capacity to make foreign exchange resources available for financing imports, supplementing foreign exchange earned from exports of goods and services, supplementing locally raised capital, and are vital for developmental programmes, budgetary and project supports. Ezenwa (2012) opined that foreign debts are needed to cover two types of gaps in the developing process, namely: the foreign exchange gap and the investment-savings gap.

Foreign debts, whether receipts or servicing, affect the economy of Nigeria. External debt receipts are inflows from debt obligations of governments to non-residents while external debt servicing is the sum of principal repayments and interest payments made to non-residents in respect of debt obligations of governments. Anyafo (1996) asserted that just as external public loans increase national income; their servicing constitutes a major leakage, more so as the capital repayment and interest due on the loans are on the available foreign exchange.

Over the years, the external debt receipts statistics of Nigerian governments show a rising trend just as the servicing component. As at 1981, the external debt receipts of Nigerian governments was N2, 331.2 million. By 1991, the debt figure increased to N328, 453.8 million. It rose further to N3, 176,291 million in 2001. It went down to $\mathrm{N} 887,953.09$ million in 2011 as a result of the debt cancellation of 2005 and rose to N1,373,569.8 million by 2013 (CBN 2010; DMO, 2013). The servicing showed a similar trend. As at 1981, the total repayment figure stood at N1, 027.41 million. By 1991 it was N26, 414.4 million. By 2001, a total of N155, 416.22 million was repaid. In 2011, the figure dropped to N55, 097.29 million as a result of the debt cancellation of 2005 and further down to N46, 294.28 million as at $31^{\text {st }}$ December 2013 (CBN, 2010; DMO, 2013).

The exchange rate indicates the price of one country's currency in relation to another country's currency. With the US dollar as the intervention currency in the market (CBN, 2010), the naira-dollar exchange rate shows the rate at which one unit of the dollar exchanges for a given units of the naira. Iyoboyi and Muftau (2014) noted that the exchange rate is an important endogenous factor that affects economic performance due to its impact on macro variables such as outputs, imports, export prices, interest rates and inflation. Depending on whether it is a fixed or flexible system, the exchange rate can be a useful factor in balance of payments adjustments, managing crises associated with pressure for currency revaluation, freeing of internal policy objectives, ability to adjust to external shocks, maintenance of foreign exchange reserves, driving of investments, and handling of speculation and level of discipline in economic management (Biz/ed, 2014).

Bergen (2014) opined that the performance of a country's exchange rate is influenced by six principal factors, namely: differentials in inflation, differentials in interest rates, current account deficits, public debt, terms of trade, and political stability and economic performance. The exchange rate statistics in Nigeria, over the years, showed a fluctuating trend. The naira-dollar end-period official cross exchange rate rose from N0.64 in 1981 to N9.7545 in 1991. It went up to N112.4864 in 2001 and by 2011 it stood at N156.7. As at 31 ${ }^{\text {st }}$ December 2013 the naira-dollar exchange rate had risen to N155.70 per one US dollar (CBN, 2010; DMO, 2013).

Borrowing and lending result in capital movement between countries with some interesting implications on the exchange rate. Jhingan (2003) has shown that short-term and long-term capital movements tend to appreciate the value of the currency of the capital-importing country by moving the exchange rate in favour of the capital-importing country. This happens because capital inflows trigger off a rise in the demand for the currency of the capital-importing country thereby shifting its currency's demand curve upward to the right and causing the exchange rate to be determined at a higher level, given the supply curve of the foreign exchange. External debt servicing, as an outflow, should produce a reverse effect.

The questions are: how did the naira-dollar end-point official cross exchange rates fluctuate (appreciate or depreciate) in relation to the external public debt receipts and servicing of the period under review? What are the implications of the mounting external debt receipts and servicing on naira exchange rate fluctuations? This study seeks to resolve the above issues.

External debt receipts of the public sector generate capital inflows that should ordinarily appreciate the value and exchange rate of the borrowing country, at least in the short-run. Servicing of such debts, on the other hand, constitutes capital outflows that should produce the opposite effect on the value and exchange rate of the naira. Black (2002) pointed out that capital movement in the form of external debt receipts and servicing form part of the capital account of the balance of payments of countries. The effect of capital inflows should, all things being equal, have a neutralizing effect on capital outflows, and hence result in a more stable naira exchange rate.

Available records from Central Bank of Nigeria (CBN) and Debt Management Office (DMO), however, show that the naira exchange rate of the period under review was not quite stable. Studies carried out by Ajayi and Jongmoo (1993), Udoka and Anyingang (2010), Sulaiman and Azeez (2012), Alam and Taib (2013), Masaku (2014), and Draz and Ahmad (2014), which were aimed at establishing a cause-effect relationship between 
public sector debt and exchange rate did not offer satisfactory explanation on the implications of the critical components of external debt receipts and servicing on exchange rate fluctuations. This study attempts to fill this gap by delving into the implications of external debt receipts and servicing on naira exchange rate fluctuations. The broad objective of this study is to determine the implications of external debt on exchange rate fluctuations in Nigeria. This study will be divided into sections one which introduction, section two has to do with review of related literature, section three will be methodology while section four will be result and analysis. Section five will be conclusion and recommendations.

\section{Review of Related Literature}

\subsection{Concept of External Public Debt}

The gap between revenue and expenditure creates the need for borrowings. Individuals, organizations and governments borrow to fill this gap. The CBN (2010) defines public debt (domestic and external) as a stock of liabilities with different tenure, accumulated by government operations in the past and scheduled to be fully repaid by government in the future. Public debt owed by the government and their agencies to residents of the country is domestic public debt, while that owed to residents of another country is foreign or external public debt. Anyanwokoro (2004) distinguishes public debt from national debt, which, as a component of public debt, is the total outstanding contractual obligations of the main stream government at various levels, exclusive of debts of government-owned institutions, agencies or parastatals. The outstanding payments on contractual obligations of the three tiers of government, namely, federal, state and local government, public corporations and parastatals make up the public debt of a country.

Nigerian governments borrow domestically through the financial markets by issuing treasury bills, federal government bonds, treasury certificates, promissory notes, treasury bonds, and development stocks (CBN, 2010). As these sources do not usually yield the desired amount of fund needed to take care of multiple government activities, governments turn to external sources, classified by the DMO into multilateral, bilateral, and commercial sources. The CBN breaks these sources into multilateral, Paris Club, London Club, promissory notes and others.

Nigerian governments borrow externally for various purposes. As Jhingan(2004) puts it, public debts are needed to finance deficit budgets, execute wars, cushion the effects of natural calamities, fund economic development plans, public enterprises and utilities as well as stabilize the economy. In line with the above driving factors, Nigerian governments' debts over the years were motivated by certain needs. In 1958, the government borrowed US $\$ 28$ millions to finance the construction of railway lines under its development programme. In the post-independence period, government borrowed to fill the deficit occasioned by the political crisis, which degenerated to a bloody civil war. The need to rehabilitate and reconstruct infrastructure damaged during the war time necessitated the borrowings of the early 1970s. The Nigerian economy got to its crisis point during the period of the global oil glut of the late 1970s, which pushed the government into debt to survive the deficit in the economy. In the quest for what was termed need for rapid economic development, the then 19 state governments joined the Federal government to accumulate more foreign debts. In the 1990s and 2000s, governments' external borrowings became instrument for managing the economy. In recent times, the downward movement in the oil revenue coupled with the need to fight poverty, unemployment, insecurity, and provide infrastructure for economic development, have resulted in more external debts.

To address the issue of mounting external public debts, the Federal government set up the Debt Management Office (DMO), a semi-autonomous establishment under the Presidency, in 2000, to centrally coordinate the country's debt recording and management activities, including debt service forecasts, debt service payments and advising on debt negotiations as well as borrowings (DMO, 2014). Before then, the task of managing the external debt of the nation was shared between five specialized departments in the Federal Ministry of Finance and three in the CBN. Ahmed (1986) notes that external debt management involves a conscious and carefully planed schedule of the acquisition, deployment and retirement of loan acquired either for development purposes or to support the balance of payments.

According to Anyanwu (1993), external debt management strategies applied by these authorities included: limiting the size of debts, limiting debt service payments, refinancing of short-term trade debts, debt rescheduling, new loan facility agreement, debt-equity swap, structural adjustment programme (SAP), and debt cancellation.

\subsection{Concept of Exchange Rate}

Exchange rate is the price of a country's currency in terms of another country's currency (Ahuja, 2013). Moffatt 
(2005) views exchange rate as the current market price for which one currency can be exchanged for another. The exchange rate determines how much a country's currency is worth in terms of another country's currency. According to Ahuja (2013), a country may operate the floating or fixed exchange rate system. The floating or flexible exchange rate system allows a currency to adjust freely as determined by the demand for and supply of foreign exchange. The fixed exchange rate is determined by the government through the Central Bank which buys and sells the required quantities of foreign exchange in order to eliminate excess demand or supply. Musgrave and Musgrave (2014) have shown that the exchange rate system operated by a country can affect the stability of the country's economy. Depending on the elasticity involved, the value of the naira relative to foreign currencies affects the balance-of-payments, the level of domestic inflation, savings, investments, and ultimately, the economy.

Nigeria operated the fixed exchange rate system prior to 1986. During this period, government used series of exchange control regulations, such as the Defence (Finance) Regulation of 1939, Exchange Control Ordinance of 1950, Exchange Control Act of 1962, Exchange Control (Anti-Sabotage) Decree of 1977, which was revised in 1984, to manage the exchange rate of the naira. With the introduction of the Structural Adjustment Programme in 1986, Nigeria switched over to the flexible or floating exchange rate system. According to CBN (2014), the main objectives of exchange rate policy in Nigeria include to preserve the value of the domestic currency, maintain a favourable external reserves position and ensure external balance without compromising the need for internal balance, and the overall goal of macro-economic stability.

\subsection{Empirical Review}

A review of previous attempts at establishing the cause-effect relationship between the variables of external public debt and exchange rate fluctuation presents some interesting results. Ajayi and Jongmoo (1993) carried out a study to verify the effect of foreign debt on currency values. The study adopted a model using combined monetary and asset perspectives of exchange rates, which included foreign debt, to estimate the impact of foreign debt on currency values. The study, which was based on a sample of less developed countries, revealed negative effect in 12 countries in the sample. The study suggested that foreign debt has an important negative effect on currency values. Foreign debt appeared to be generally linked to capital flight and trade deficit, resulting in a depreciation of domestic currency, though in the case of the exceptions such as Israel and Singapore, foreign debt implied excess demand for domestic assets from foreign investors, which can have a negative effect on exchange rate.

Udoka and Anyingang (2010) undertook a study to appraise the relationship between external debt management policies and economic growth in Nigeria, from 1970 to 2006. The study formulated one null hypothesis to determine the effect of external debt on gross domestic investment, exchange rate, fiscal deficit, and terms of trade. Ex-post facto research design was adopted and Ordinary Least Square multiple regression technique was used to analyze data gathered for the study. The result of the findings revealed that GDP, exchange rate, fiscal deficit, London Interbank official rate, and terms of trade were the major determinants of external debts in Nigeria.

Sulaiman and Azeez (2012) investigated the effect of external debt on the economic growth of Nigeria, using econometric techniques of Ordinary Least Square, augmented dickey-fuller (ADF) unit root test, Johansen co-integration test and error correction method (ECM) in its analysis of gathered data. The model built for the study proxy, gross domestic product, as the endogenous variable measuring economic growth as a function of eternal debt, ratio of external debt to export, inflation, and exchange rate proxy as the exogenous variable. The co-integration result showed that long-run equilibrium relationship exists, among the variables. Findings from the error correction method showed that external debt has contributed positively to the Nigerian economy.

Alam and Taib (2013) investigated the relationship of external public debt (EPD) with budget deficit (BD), current account deficit (CAD), and exchange rate depreciation (ERD) by empirically analyzing panels of a group of six "debt-trap countries (DTC)" and eight "non-debt-trap countries (NDTC)". The study applied the panel OLS regression with fixed and random effects modeling (FEM and REM, respectively) to show a positive relationship of EPD with $\mathrm{BD}, \mathrm{CAD}$, and ERD with varying strength of relationship in DTCS and NDTCS. It further showed that a strong coefficient of EPD, BD and ERD indicated an explosive borrowing, a higher demand of EPD and heavy utilization of foreign exchange while a lower coefficient of EPD, BD and ERD indicated less borrowing, less demand of debt and less utilization of foreign exchange. A lower coefficient of CAD suggested that borrowed funds were not directed towards, adjustment in current account in NDTCs, signaling a prudent public debt management in NDTCs compared to DTCs.

Masaku (2014) investigated the effect of Kenya's external debt on exchange rate fluctuations. A correlation 
design was selected for the study and SPSS was employed to analyze data, using descriptive statistics, correlation and regression techniques. Population and subsequent sample size was 360 data points covering a period of 40 years, from 1971-2010, with nine variables. The dependent variable used was external debt while the control variables were GDP, interest rate, inflation rate, terms of trade, net foreign assets, exchange rate, and government expenditure. The study found that there was a general upward trend in both external debt and exchange rate fluctuations. The study further revealed that external debt, interest rate and not foreign assets had a positive and significant effect on exchange rate. On the other hand, inflation rate and FDI inflows had negative and significant effects on exchange rate. External debt accounted for $63 \%$ of the foreign exchange volatility. The study concluded that Kenya's external debt positively and significant affects her exchange rate fluctuations.

\subsection{Theoretical Framework}

There exist theories that seek to explain the relationship between the variables of components of external public debt and exchange rate fluctuation. The theoretical framework of this study shall, however, be based on the monetary model of exchange rate determination and the monetary approach to international capital movements, which are considered to be more relevant to the variables and focus of the study.

\subsubsection{Monetary Model of Exchange Rate Determination}

The monetary model of exchange rate determination was developed by notable scholars, prominent among who is Michael 1. Mussa. Mussa in his 1976 and 1984 seminal work on "Theory of Exchange Rate Determination" applied the monetary model to show that the current exchange rate is a function of the current stocks of domestic and foreign money and the current determination of the demands for these monies, including domestic and foreign income and interest rates. According to Mussa (1984), since an exchange rate is the relative price of one nation's money in terms of the money of another nation, it is natural to think of an exchange rate as determined, at least primarily, by the outstanding stocks of these monies and by the demands to hold these stocks.

\subsubsection{Monetary Approach to International Capital Movement}

Attempts to explain the factors that influence international capital movements resulted in three theories, namely: the flow theory, the stock theory and the monetary approach to capital movements. While the first two theories focus on the role of interest rate differential between countries as principal factor that influences international capital movements, the monetary approach concentrates on the factors that may cause a change in foreign currency reserves, and hence the money supply. According to Sobersten and Reed (1994), the monetary approach, which was popularized through the 1976 seminal works of scholars like Frenkel, Johnson and Mussa, argues that money supply and demands are strong forces in determining a country's external position, as indicated by the change in the country's foreign currency reserves. The model concludes, that starting from an initial equilibrium position, an increase in the demand for money (or an increase in its supply) will lead to a balance-of-payments (BOP) surplus or vice versa, which will in turn affect the exchange rate either positively or negatively.

\section{Methodology}

The objective of this study were achieved using the causal-comparative (ex-post facto) research design to establish the cause-effect relationship between the variables of external public debt receipts and exchange rate fluctuations. Secondary data were gathered from CBN bulletins and DMO statistical publications. Data collected would have been analyzed and tested using the parametric statistical techniques of multiple regressions (Ordinary Least Square) and Co-integration with the aim of establishing the short-run and long-run relationship between these variables. The following general equation for OLS and Co-integration test were adopted:

$$
E X R t=\beta o+\beta_{1} E P D R_{1} t+\beta_{2} P D S+\mu t
$$

where:

$$
\begin{aligned}
& Y t=\text { the dependent variable; } \\
& \beta_{0}=\text { the intercept term; } \\
& \beta_{1}=\text { the regression coefficient; } \\
& \mathrm{xt}=\text { set of explanatory variables and; } \\
& \mu \mathrm{t}=\text { the error term. }
\end{aligned}
$$

The fore-going presentation were re-specified as shown below to capture the objectives of the study:

$$
E X R=F(E P D R, P D S)
$$

Where: 
EXR=the naira exchange rate

EPDR=the external public debt receipts, and

PDS=public debt servicing (used as proxy for external public debt servicing).

\section{Results and Analysis}

\subsection{Unit Root Test}

Aliyu (2001) states that it has been in practice among researchers that macroeconomic data are characterized by a stochastic trend and if untreated, the statistical behaviour of the estimators is influenced by such trend. This means that it has become conventional rule to examine stationarity of the chosen variables in econometric studies like ours to obtain a reliable result. Ajab and Audu (2006) opine that the outcome of working with non-stationary variables leads to spurious regression results from which further reference or result may be meaningless. This test tries to examine the property of the variables. It is used to check for the presence of a unit root. This test is carried out using the Augmented Dickey-Fuller (ADF) test. This is the first test carried out in the co-integration analysis and is known as the pre co-integration test. The results of the unit-root tests are presented below:

Table 1. Results of Augmented Dickey-Fuller (ADF) unit root test with intercept

\begin{tabular}{lcccccc}
\hline Series & ADF TestStatistic & 1\%CriticalValue & $\begin{array}{c}5 \% \text { CriticalVa } \\
\text { lue }\end{array}$ & 10\%CriticalValue & Order ofintegration & Remark \\
\hline EXR & -6.110942 & -3.596616 & -2.933158 & -2.604867 & 1(1) Stationary & $@ 1 \%, 5 \% \& 10 \%$ \\
EPDR & -7.713802 & -3.600987 & -2.935001 & -2.605836 & 1 (1) Stationary & $@ 1 \%, 5 \% \& 10 \%$ \\
PDS & -4.468217 & -3.646342 & -2.954021 & -2.615817 & 1(1) Stationary & $@ 1 \%, 5 \% \& 10 \%$ \\
\hline
\end{tabular}

Source: Author's Calculation 2015 (Extracted from E-View 7.0 output).

The a priori expectation when using the Augmented Dickey-Fuller (ADF) test is that a variable is stationary when the value of the Augmented Dickey-Fuller (ADF) test statistic is greater than the critical value at $1 \%, 5 \%$, and $10 \%$. All of the variables used met this a priori expectation at first difference. The above empirical ADF test in tables 1 shows that the variables (EXR, EPDR, and PDS) are integrated of order one (1) both with intercept and trend and intercept. They are integrated of the same order; 1(1). The unit root test tests for the existence of a unit root with intercept and trend to make into the account the impact of the trend on the series.

\subsection{Co-Integration Test}

Having confirmed that the variables (EXR, EPDR, and PDS) were stationary at their first difference 1(1) which denoted that the variables are of the same order of integration, the next thing is to determine the number of long run equilibrium relationships of co-integrating vectors among the variables. Azeez, kolapo and Ajayi (2012) opine that when series are found to be integrated of the same order, it implies that an equilibrium relationship exist among variables. In this study, when a co-integration relationship is present, it means that external debt servicing and exchange rate share a common trend and long-run equilibrium as suggested theoretically. In this study, we employ Johansen cointegration approach to verify whether a stable long-run relationship exists between the external debt servicing and exchange rate in Nigeria. The co-integration test result is presented below:

Table 2. Johansen co-integration result for the series: EXR, EPDR, and PDS (EXR = F (EPDR, and PDS)) using trace statistic

\begin{tabular}{ccccc}
\hline Eigenvalue & Trace Statistic & 0.05 & Prob.** & Hypothesized \\
\hline 0.837644 & 265.2631 & 125.6154 & 0.0000 & None* \\
0.786012 & 188.9086 & 95.75366 & 0.0000 & At most $1 *$ \\
0.678314 & 124.1516 & 69.81889 & 0.0000 & At most $2 *$ \\
\hline
\end{tabular}

Source: Author's Calculation 2015 (Extracted from E-View 7.0 output).

$*(*)$ denotes rejection of the hypothesis at 5\% significance level. L.R test indicates 5 co-integrating equation(s) at $5 \%$ level of significance. Normalized Cointegrating Coefficients: 1 co-integrating Equation(s).

Where EXR is the dependent variable, -0.000101 is the coefficient of EPDR and -1.6 is the coefficient of PDS 
while -2376.930 is the constant term.

From the above cointegration equation, all the exogenous variables have a long run relationship with unemployment rate.

\subsection{Error Correction Model (ECM) Using OLS}

The analysis in this section seeks to examine the short run implication of external debt servicing and exchange rate. The motive of the analysis is to discover whether the short run dynamics are influenced by the estimated long run equilibrium conditions that are the co-integrating vectors. Since co-integration is a prerequisite for the Error Correction Mechanism. The results of the co-integration confirm the existence of an underlying long- run stationary steady- state relationship between the dependent and independent variables under consideration. This is because co-integration analysis does not give estimates with structural interpretation regarding the magnitude of the parameters of the co-integrating vectors. In the instance, ECM is considered the best option for estimation of equation 1 above to determine the dynamic behaviour of exchange rate. The ECM has the ability to restrict the long run behaviour of the independent variables to converge to their co-integrating relationship while allowing for short-run adjusted dynamic. In order to straighten out or absolve these fluctuations, we employ the Error Correction Model (ECM).

Table 3. OLS result

\begin{tabular}{lclcc}
\hline $\begin{array}{l}\text { Dependent Variable: EXR } \\
\text { Method: Least Squares } \\
\text { Sample: } 1981 \text { 2013 }\end{array}$ & & & & \\
Included observations: 31 & & & & \\
\hline \multicolumn{1}{c}{ Variable } & Coefficient & Std. Error & t-Statistic & Prob. \\
\hline \multicolumn{1}{c}{ EPDS } & 34.40269 & 10.83205 & 3.176009 & 0.0036 \\
\multicolumn{1}{c}{ EPDR } & 3.465244 & $6.93 \mathrm{E}-05$ & 3.520299 & 0.0015 \\
\hline R-squared & 1.754355 & $7.34 \mathrm{E}-06$ & 1.435229 & 0.0003 \\
Adjusted R-squared & 0.808635 & Mean dependent var & & 73.54904 \\
S.E. of regression & 0.773537 & S.D. dependent var & & 60.77004 \\
Sum squared resid & 44.09337 & Akaike info criterion & & 10.50226 \\
Log likelihood & 54438.31 & Schwarz criterion & & 10.64103 \\
F-statistic & -159.7851 & Hannan-Quinn criter. & & 10.54750 \\
Prob(F-statistic) & 14.49206 & Durbin-Watson stat & & 1.425520 \\
\hline
\end{tabular}

The table above shows the OLS result. From the OLS result, it could be seen that there is a positive relationship between exchange rate (EXR), external public debt receipts (EPDR) and external public debt servicing (EPDS), which implies that as public debt receipts and servicing increase, exchange rate increases over time. The result shows that there is a direct/positive relationship between EXR and EPDR, that is, 1 unit increase in EPDR will lead to 1.754355 unit increase in EXR. There is also a direct/positive relationship between EXR and EPDS which implies that, unit increase in the will lead to 3.465244 unit increase in EXR. The cointegration test shown above indicates that there is a long-run relationship between the dependent variable (EXR) and the independent variables (EPDR and EPDS) within the period reviewed (1981-2013).

From the empirical evident, it could be inferred that the coefficient of regression, which is the coefficient that depicts the estimated coefficient, appears to be good, while standard error and the values of t-statistic have been shown. The results of other important statistical tools applied in this study reveal that the coefficient of determination ( $\mathrm{r} 2$ ), as used to measure the success of the regression in predicting the value of the dependent variables within the sample and test the goodness of fit, is considered high (over 80.86\%). The adjusted R-square, the Durbin-Watson statistics and the entire regression test are statistically significant, including the f-test. Durbin-Watson statistic suggests that there is serial correlation in the error term. All results were obtained empirically, based on availed secondary data, and the test was conducted at five percent $(5 \%)$ level of significance. The result indicates that the level of Nigeria's external public debt receipts over the years have significant positive effect on naira exchange rate fluctuation. External public debt servicing, on the other hand, has a negative effect on the exchange rate. 


\section{Conclusion and Recommendations}

\subsection{Conclusion}

The external public debt receipts and servicing of Nigeria and the naira exchange rate over the reviewed period (1981-2013) show a rising trend. Apart from 2006 and 2007 when the external loan stock and exchange rate declined as a result of the debt cancellation of 2005, the pre-and post-debt cancellation periods' statistics show an upwards movement for both the external debt stock (receipts and servicing) and the naira exchange rate. This picture shows a positive relationship between the variables of external debt receipts and servicing and the naira exchange rate. This observation agrees with the results of some empirical studies reviewed in this work, which would have been confirmed had this study been empirically carried out using the OLS and Co-integration analytical techniques. The study, therefore, concludes that EPDR affect significantly and positively the value and exchange rate of the naira, while EPDS affects the value and exchange rate of the naira negatively; both variables have a positive long-run relationship with EXR. The policy implication of this study is that government should evolve more efficient external debt management strategies that would ensure that foreign loans which will not enhance the value and exchange rate of the naira are avoided. This is necessary because of the vital roles exchange rate plays in the economic growth of any nation. It further implies that the absence of a balancing-off effect of the variables of EPDR and EPDS on exchange rate fluctuations could indicate that other factors beside EPDR and EPDS could have contributed to the instability in the naira exchange rate of the reviewed period.

\subsection{Recommendations}

Based on the findings of this study, it is recommended that, for a more economy-friendly exchange rate, Nigerian governments should adopt the following measures:

1) Nigerian governments should always strive to secure self-liquidating, production-based/project-tied external loans for financing projects;

2) Embargo on certain classes of foreign loans as well as the frequency of contracting loans should be placed and effectively enforced;

3) Foreign loans with concessionary low interest rates and long maturity periods should be contracted;

4) External loans should be serviced promptly and regularly to avoid the burdensome effect of accumulated compound interests;

5) Misappropriation of external loan resources should be stopped; and

6) Further researches could be carried out to reveal those other factors, if any, beside EPDR and EPDS that could have led to the exchange rate fluctuations of the reviewed period.

\section{References}

Adams, R.A. (2013). Public sector accounting and finance made simple(3rd ed.). Lagos: Corporate Publishers Ventures.

Ahmed, A. (1986). Debt management and Nigeria's balance of payments.Bullion, 10(4).

Ahuja, H. L. (2013). Modern Economics, 10(4), 545. New Delhi: S. Chard \& Company Pvt. Ltd.

Ajayi, R. A.,\& Jongmoo, J.C. (1993). The effect of foreign debt on currency values.Journal of Economics and Research.Retrieved from http://www.readabstracts.com/economics/The-effect-of-debt-on-currency-values

Alam, N.,\& Taib, F. M. (2013). An investigation of the relationship of external public debt with budget deficit, current account deficit, and exchange rate depreciation in debt-trap and non-debt trap countries.European Scientific Journal, 9(22), 144-158.

Anyafo, A. M. O. (1996). Public finance in a developing economy: The Nigerian case(pp. 303-323).UNEC, Nigeria: B \& F Publications.

Anyanwokoro, M. (2004). Elements of public finance(pp. 146-147). Enugu:Hosanna Publications.

Anyanwu, J. C. (1993). Monetary economics: Theory, policy and institutions onitsha. Hybrid Publishers Ltd.

Begg, D., Fisher, S., \& Dornbusc, R.(1991). Economics (3rded.). England: Mcgraw-Hill Book Company Europe.

Bergen, J. V. (2014). 6 factors that influence exchange rates. Retrieved from http://www.investopedia.com/article basics/04/05070

Biz/Ed. (2014). Advantages and disadvantages of floating exchange rates. Retrieved from 
http://www.bized.co.uk/virtual/bank/ economics/markets

Black, J. (2002). Oxford dictionary of economics (2nd ed.). New York: Oxford University Press.

CBN. (2014). Central bank of Nigeria: Foreign exchange management. Retrieved from http://www.cbn.gov.ng/intops/ fmanagement.asp

Cecchetti, S.G., Mohanty, M.S.,\& Zampolli, F. (2011). The real effects of debt.BIS Working Papers, No. 352. Retrieved fromhttp://www.bis.org/publ/work 352.html

Central Bank of Nigeria. (2010). Statistical Bulletin, 21, 91-228.

Debt Management Office. (2014). Strengthening debt management in Nigeria.Retrieved from http://www.unitar.org/dfm/generalinfo/fambiaworkship

Debt Management Office. (n. d.). Act, No. 18, 2003.Retrieved from http://www.babalakinandco.com/.../laws

Debt Management Office. (2013).Nigeria's external debt stock.

Draz, M. U.,\& Ahmed, F. (2014). External debts and exchange rates of oil-producing and non-oil-producing nations: Evidence from Nigeria and Pakistan.Journal of Advanced Management Science, 3(1).

Ezenwa, C. S. (2012).The effect of external debt on economic growth of Nigeria (1981-2010).A Project Presented to the Department of Economics, Caritas University, Emene Enugu, in Partial Fulfilment for the Award of Bachelor of Sciences (B.Sc) Degree in Economics. Retrieved from http://www.pubs.caritasuni.edu.ng/downloard.php

Iyoboyi, M.,\& Muftan, O. (2014). Impact of exchange rate depreciation on the balance of payments empirical evidence from Nigeria. Cogent Economics and Finance, 2(1).

Jhingan, M. L. (2003).Macro-economic theory (11thed., pp. 770-771). Delhi India: Vrinda Publications (P) Ltd.

Jhingan, M. L. (2004). Money, banking, international trade andpublic finance (7thed., pp. 802-803).Delhi India: Education, Vrinda Publications (P) Ltd.

Masaku, J. N. (2014). An investigation of the effects of Kenya's external debt on exchange rate fluctuations. Retrieved on February 22, 2015 fromhttp://www.researchkenya.or.ke/node/40849

Exchange rate volatility, stock price fluctuations and the lending behaviour of banks in Nigeria. Journal of Economics and International Finance, 2(11), 251-160.

Mofatt, M. (2015). Definition of exchange rate. Retrievedon February15, 2015 from $\mathrm{http}: / / \mathrm{www} . e c o n o m i c s . a b o u t . c o m / c s / e c o n o m i c s g l o s s a r y / e x c h a n g e$ rate

Musgrave, R. A.,\& Musgrave, P. B. (2004). Public finance intheory and practice (5thed.). Tata New Delhi: McGraw-Hill Publishing Company Limited.

Mussa, M. L. (1984). The Theory of Exchange Rate Determination.In J. F. O. Bilson,\& R. C. Marston (Eds.), NBER book exchange rate theory and practice (pp. 13-78).

Sobersten, B. O.,\& Reed, G. (1994). International economics (3rded.). London: Macmillan Press Ltd.

Sulaiman, L.A.,\& Azeez, B. A. (2012). Effect of external debt on economic growth of Nigeria.Journal of Economics and Sustainable Development, 3(8).

Udoka, C. O.,\& Anyingang, R. A. (2010). Relationship between external debt management policies and economic growth in Nigeria (1970-2006).International Journal of Financial Research, 1(1), 2-13. http://dx.doi.org/10.5430/ijfr.v1n1p2

Ugwu, M.J.O.(2011). Public finance in Nigeria: An integrated approach. Abakaliki: Ugub's Printing and Publishing Co.

\section{Copyrights}

Copyright for this article is retained by the author(s), with first publication rights granted to the journal.

This is an open-access article distributed under the terms and conditions of the Creative Commons Attribution license (http://creativecommons.org/licenses/by/3.0/). 